\title{
PECULIARITIES OF SPORTS INJURES OF SPRINT AND THROWING COHORTS IN TRACK AND FIELD ATHLETICS
}

\author{
Linas Rekus, Evelina Rekuvienė, Aušra Burkauskienė, Daiva Emilija Rekienė, \\ Žibuoklè Senikienė, Audrius Paršeliūnas, Egidijus Šakalys \\ Lithuanian University of Health Science, Medical Academy, Kaunas, Lithuania
}

\begin{abstract}
Research background and hypothesis. The severity of recurrence of injuries in track and field athletics gives possibility to adjust training programs for athletes.

Research aim was to analyse which body parts are mostly injured and the severity of recurrence of injuries in track and field athletics gives possibility to adjust training programs for athletes.

Research methods. Thirty six athletes were given questionnaires developed using standardized methodology validated by the IOC and implemented by the IAAF during international track and field competitions.

Research results. There were 64 cases of injuries among 33 athletes: head and trunk cases $-12(18.8 \%)$, upper extremity - 14 (21.9\%), lower extremity - 38 (59.4\%). In all cases lower extremity injuries dominated. In sprinters lower extremity injuries dominated and there was no upper extremity trauma. In throwers the upper and the lower extremity were equally vulnerable, mild and very mild injuries were observed. There was no difference between both groups in recurrence of the same trauma.

Discussion and conclusions. Estimating which body parts are mostly injured in sports gives the possibility to adjust training programs for athletes, increasing the amount of athletic exercises intended for the functional preparation of those parts. Injuries in track and field are frequent and dominating injuries are of lower extremity; there exist the possibility of recurrence of the injury in the same body part. Injuries prevalent in sprinter cohort are of lower extremities, and injuries prevalent in throwing cohort are of lower and upper extremities.
\end{abstract}

Keywords: track and field, sports injury, body areas.

\section{INTRODUCTION}

$O$ port requires extreme workloads and skills and each athlete may be hampered by a prolonged absence from competitive activity through injury. Injuries in track and field athletics are an important and relevant problem as well. It is not completely examined, the scientific literature on the risk of injuries in track and field athletes is still scarce (Alonso et al., 2009), and the same problem exists in Lithuania as well. Some authors analysed the frequency characteristics and causes of injuries during the Summer Olympic Games of 2008 (Junge et al., 2009). All sports injuries in competitions and/or training during the 2007 World
Athletics Championships (Alonso et al., 2009) were analysed, too. Most of the injuries involved the lower extremity $(79.8 \%)$ which is similar to previous studies in Athletics. (Watson, Di Martino, 1987; Bennell et al., 1996; Zemper, 2005; Alonso et al., 2009; Graff, Birken, 2009 a, b, c; Junge et al., 2009; Alonso et al., 2012). In the article on sports injuries surveillance during the 2007 IIAF World Athletics Championships the authors (Alonso et al., 2009) write that eighty per cent of athletes affected their lower extremities.

The aim of this study was to analyse which body parts were mostly injured, as the severity of 
recurrence of injuries in track and field athletics gives possibility to adjust training programs for athletes. The objects of study were athletes with injuries in Lithuania in 2011.

\section{RESEARCH METHODS}

The objects of the study were athletes with injuries in Lithuania in 2011. We used a strategy of random sampling. The questionnaire was given to athletes in their training and competitive places in Lithuania. The sample included 36 athletes, men $(\mathrm{n}=26)$ and women $(\mathrm{n}=10)$, they aged from 18 to 39 years. The mean age of athletes was $21.8 \pm$ 4.8 years. Sports experience in years was $8 \pm 4.5$. Training sessions were $5.1 \pm 1.7$ on average per week. The mean duration of one training session was $99.17 \pm 24.03$ minutes. All 36 athletes had competition experience in Lithuania's Track and Field Championship in 2011. Six athletes had covered the normative requirements of London Olympics games. We examined the injury cases of 15 throwers: 8 javelin throwers, 4 discus throwers, 3 shot putters and 21 sprinters. There were 64 traumatic injury cases.

Instruments. Thirty six athletes were given questionnaires developed using standardized methodology (Daily Report on Injuries and Illnesses, codes and classifications) validated by the International Olympic Committee (IOC) and implemented by the IAAF during international track and field competitions, during the period of the Daegu 2011 IAAF World Championships (27 August to 4 September). We applied it in cases of injuries at the track and field all year round in 2011during training sessions and competitions, meanwhile the IOC used it only at the time of Olympic Games, also at the world track and field championships. In our questionnaire, there were 13 questions: 1. Sex; 2. Age and date of birth; 3. Number of training years in track and field; 4. Average number of training sessions per week; 5. Average length of a training session; 6. Event; 7. Are you competing in Lithuanian track and field championships? 8. Have you fulfilled Olympic requirements for London Olympic Games? 9. Number of injuries in 2011; 10. Point out injured body parts on the human silhouette picture (we classified body parts similarly to validated IOC and IAAF standardized classification): Head and trunk: a. face. head, c. neck, d. upper back, e. pectoral area, f. lumbar area, g. abdomen, j. pelvis/sacrum/gluteal area. Upper extremity: a. Shoulder, b. elbow, c. forearm, d. wrist, e. hand, f. finger. Lower extremity: a. Inguinal, b. Quadriceps area, c. Hamstrings area, d. popliteal area, e. Knee area, f. Calf, g. Achilles, h. Ankle, i. Foot. 11. Evaluate the severity of every injury in 5 points as shown below: I very mild injury (no missed training sessions), II. Mild injury (1 to 7 training days missed), III. Moderate injury (about 2 weeks of training missed), IV. Severe injury (from 2 weeks up to 3 months of training missed); V. Very severe (training stopped for 6 months and more). Our questionnaire did not have a question about a kind of trauma and its causes as not all athletes who suffered very mild injuries had turned for medical care. That is why a questionnaire had been given not to doctors but to athletes themselves. Without adding questions about damaged structures and type of injuries we presume that not all athletes can remember the clinical diagnosis. If the athlete with a mild injury did not seek doctors' care, he/she is unable to objectively assess the type of anatomic structure damage and the injury type. We used the silhouette of the figure of the human body upon which an athlete pointed out injured body parts and noted the time when they were in poor health and how much time they could not work out. By the number of missed training and competition days we made the classification of the degree of injury severity. We are investigated how much and what kind of injuries the athlete had suffered as well as a recurrence of the same injury over the period of 2011. As javelin throwers, shot putters and discus throwers' training principles and some technical moments had much in common with each other, we combined them into one group called the Throwers. The same was done with sprint types: $100 \mathrm{~m}, 200 \mathrm{~m}, 400 \mathrm{~m}, 4 \times 100 \mathrm{~m}, 4 \times 400 \mathrm{~m}$, we called them the Sprinters, similar event categories were distinguished in the article "Track and field athletics injuries - a one-year survey" written by David D'Souza MB ChB and published by British Journal of Sports Medicine in 1994. Due to this, we suspected to have more accurate results on the injured body parts and the areas of injury.

Data analysis was performed using Statistical Package for Social sciences (SPSS) version 17. Mann Whitney U test was used for nonparametric two independent samples, Student's t-test for independent samples was used for the significance of the difference between the means of groups. We chose the significance level of 0.05 


\section{RESEARCH RESULTS}

During the chosen study period we examined 36 athletes: 15 throwers ( 8 javelin, 4 discus, and 3 shot putters), 21 sprinters. Three athletes from 36 (1 thrower and 2 sprinters) did not have injuries. Statistically significantly more athletes experienced injuries $(\mathrm{p}<0.05)$. There were 64 injuries cases from these 33 athletes: head and trunk $12(18.8 \%)$ : neck $1(1.6 \%)$, chest $1(1.6 \%)$, back $2(3.1 \%)$ lumbar
5 (7.8\%), gluteal $3(4.7 \%)$. Upper extremity 14 (21.9\%): wrist 1 (1.6\%) elbow $4(6.3 \%)$ shoulder 9 (14.1\%). Lower extremity 38 (59.4\%): foot $1(1.6 \%)$, ankle $13(20.3 \%)$, Achilles $4(6.3 \%)$, calf $1(1.6 \%)$, popliteal $2(3.1 \%)$, knee 5 (7.8\%), inguinal $3(4.7 \%)$ quadriceps $2(3.1 \%)$, hamstrings 7 (10.9\%) (Figure $1,2)$. The lower extremity injuries statistically significantly dominated comparing with upper extremity $(\mathrm{p}<0.05)$ and head and trunk $(\mathrm{p}<0.05)$ injuries.

Figure 1. All injuries cases analysed in study

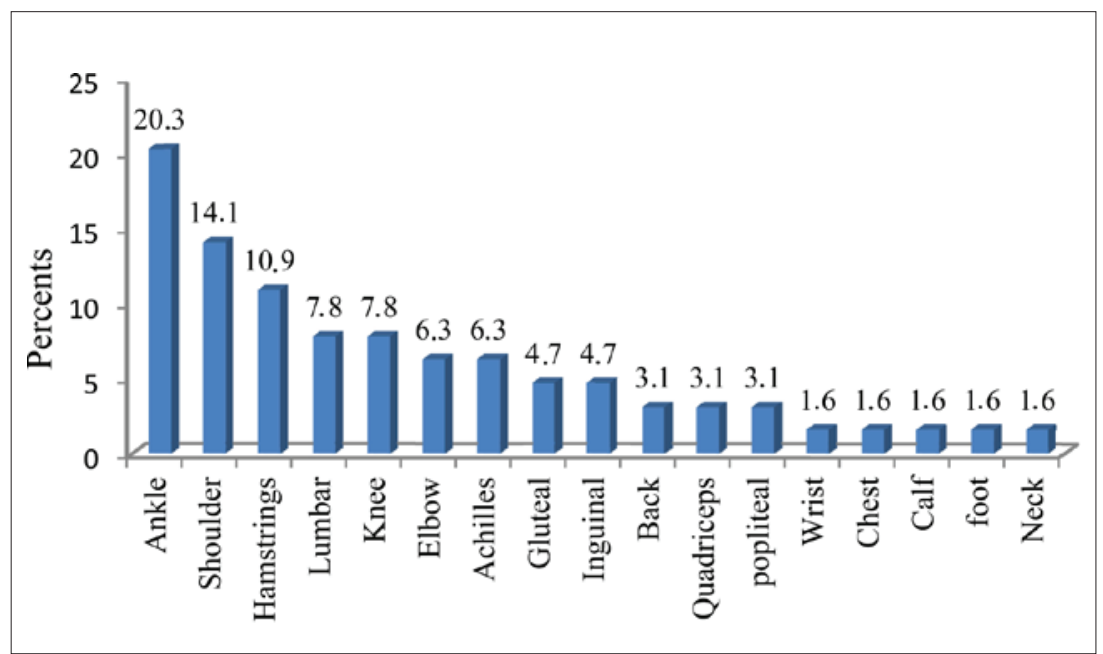

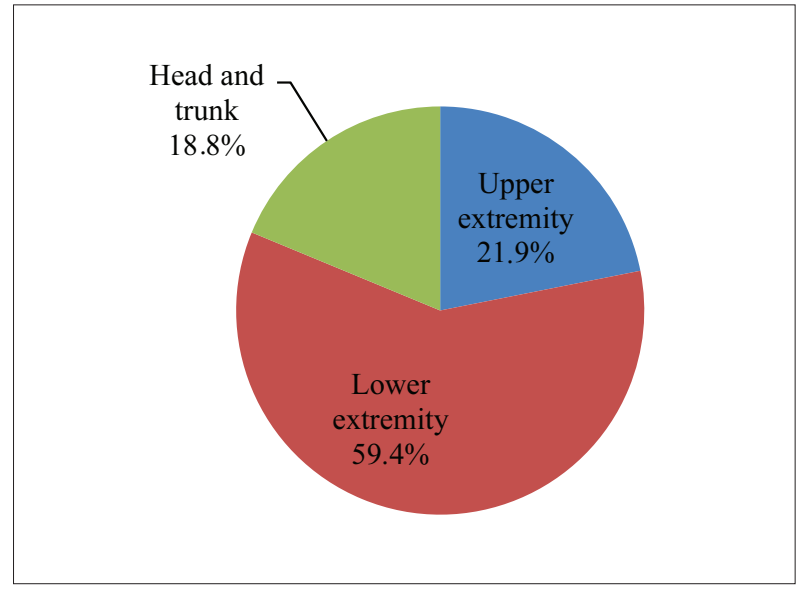

Figure 2. Distribution of injury cases by body parts in thrower and sprinter cohorts

In the group of throwers 14 athletes had 33 cases of injuries; from the group of sprinters 19 athletes had 31 injuries, so overall 33 athletes experienced 64 cases of injuries.

From 33 injury cases in the throwers group, body injuries were classified as: upper extremity 14 (42,4\%): shoulder - 9 (27.3\%), elbow - 4 (12.1\%) wrist $-1(3 \%)$, lower eextremity - $14(42,4 \%)$ : ankle - 5 (15.2\%), Achilles - 2 (6.1\%), hamstrings $1(3 \%)$, inguinal $-1(3 \%)$, knee $-4(12.1 \%)$, calf -1
(3\%), head trunk - 5 (15.2\%): lumbar - 2 (6.1\%), back $-2(6.1 \%)$, chest $-1(3 \%)$ (Figures 3, 5). There was no statistically significant difference between lower and upper extremities in this group.

In the sprinters' group, from 31 injuries 24 (77.4\%) were in the lower extremity: foot -1 (3.2\%), knee - 1 (3.2\%), Achilles - 2 (6.5\%), ankle$8(25.8 \%)$, quadriceps $-2(6.5 \%)$, hamstrings -6 (19.4\%), popliteal $-2(6.5 \%)$, inguinal $-2(6.5 \%)$, head and trunk $-7(22.6 \%)$ injuries: neck -1 (3.2\%), lumbar - 3 (9.7\%), gluteal - $3(9.7 \%)$ and no upper extremity injuries (Figures 4,6 ).

Comparing upper extremity injuries in throwers and sprinters, upper extremity injuries dominated statistically significantly $(p<0.05)$ in the throwers' group.

Lower extremity was injured in sprint (24 cases) rather than in throwers (14 cases).

There were more very mild and mild injuries 47 cases $(73.4 \%)$ compared with severe and very severe injuries - 11 cases (17.2\%) in both groups $(p<0.05)$ (Table).The degree of mild and very mild injuries dominated in both groups of athletes comparing them with very severe and severe injuries. 


\section{Recurrence of the same injury:}

From 31 injury cases in sprinters, 2 athletes had the same area injury recurrence:

- For 1 athlete trunk injury recurred 2 times;

- For 1 athlete ankle injury recurred 2 times.

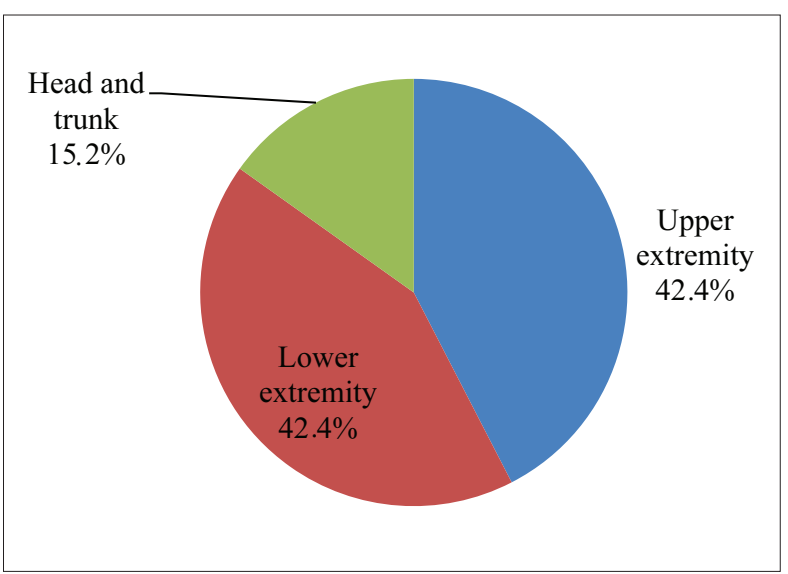

Figure 3. Throwers' injured body parts

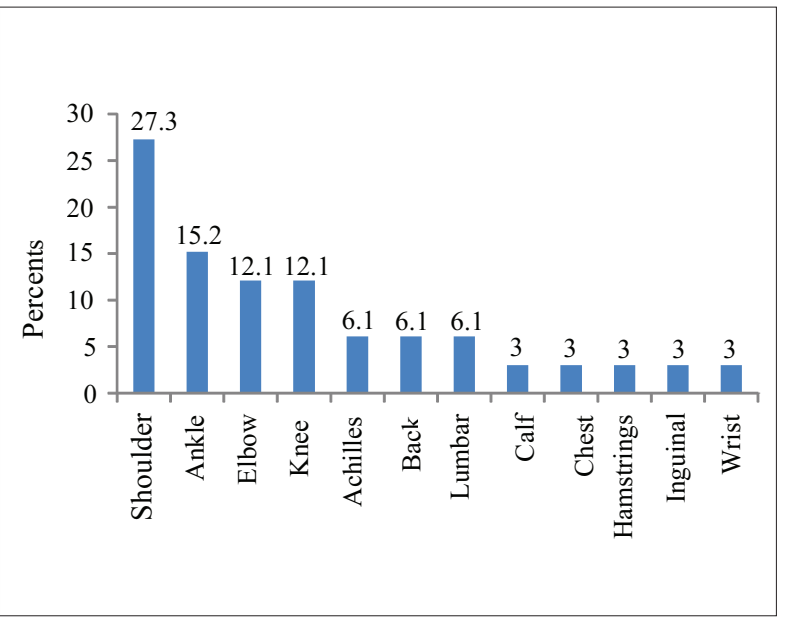

Figure 5. Injuries in thrower cohort
- From 33 injury cases in throwers, 2 athletes had the same area injury recurrence:

- For 1 athlete shoulder injury recurred 2 times;

- For 1 athlete knee injury recurred 2 times.

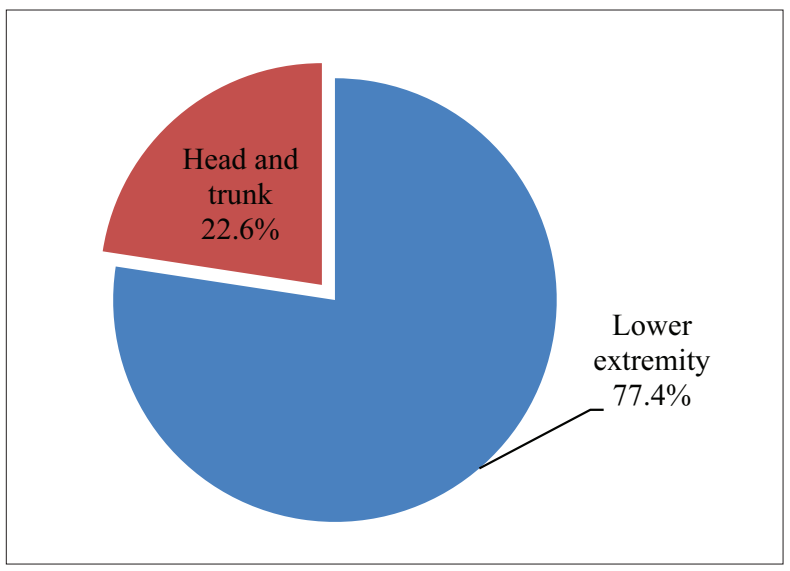

Figure 4. Sprinters injured body parts



Figure 6. Injuries in sprinter cohort

Table. Severity degree of examined injuries among throwers and sprinters

\begin{tabular}{|l|c|c|}
\hline \multicolumn{1}{|c|}{ Severity degree of injuries } & Number of injury cases & Percent of injury cases \\
\hline Very mild injuries & 23 & 35.9 \\
\hline Mild injuries & 24 & 37.5 \\
\hline Moderate injuries & 6 & 9.4 \\
\hline Severe injuries & 9 & 14.1 \\
\hline Very severe injuries & 2 & 3.1 \\
\hline Totally & 64 & 100 \\
\hline
\end{tabular}




\section{DISCUSSION}

Youth have very high participation rates in sport, and sport is the leading cause of youth injury in many countries (Emery, 2010). The injury prevalence is high among Swedish elite track and field athletes (Jacobsson et al., 2012). The most common injury cases in our work were the lower extremity injuries (59.4\%). The dominant areas in lower extremity were ankle (20.3\%), hamstrings (10.9\%) (Figure 1). Similar results were obtained by some authors: most of injuries affect the lower extremities (Watson, Di Martino, 1987; Bennell, Crossley, 1996; Pastre et al., 2004; Zemper, 2005; van Gent et al., 2007; Graff et al., 2009; Owoeye et al., 2009; Alonso et al., 2010; Jacobsson et al., 2012). There is a lack of scientific works about athletes' injuries in track and field in Lithuania. We examined 36 athletes and their 64 injury cases and found that the frequency of injuries in these athletes was high. In our work the most common cases in sprinters' group were the lower extremity injury cases - $24(77.4 \%)$. The dominant areas of lower extremity were ankle $-8(25.8 \%)$, hamstrings -6 (19.4\%). In throwers' group, the lower extremity injuries were most frequent in the areas of ankle $5(15.2 \%)$, knee $-4(12.1 \%)$ and in upper extremity the most frequent place was shoulder - 9 (14.1\%). There were no upper extremity injury cases in sprinters' cohort.

Due to our work, sports physicians in Lithuania can better prepare to provide medical treatment as they know what parts of body are most frequently injured. We expected to find the most common injured body parts in Athletics and we hope that our results will be similar to the ones of foreign authors. Knowing what areas of the body are most injured among the track and field athletes, in the future we will be able to analyze what kind of structure and nature the injury is.

The scientific rigor used in the selection and application of statistical analysis techniques is critical to avoid reporting misleading results (Emery, 2010). One of the limitations in this study was the limited number of cases available for such analysis but the results obtained during the study allow distinguishing the tendencies. It is well known that using specific training programmes, it may be possible to reduce the incidence injuries (Bahr, Krosshaug, 2005). Knowing which body parts could be damaged during active exercising in one or other athletic event we suggest to adjust specific training programs for young athletes, increasing the amount of exercises designed for the functional preparation of those body parts.

\section{CONCLUSIONS AND PERSPECTIVES}

1. Estimating which body parts are mostly injured in sports gives possibility to adjust training programs for athletes, increasing amount of athletic exercises intended for the functional preparation of those parts.

2. Injuries in track and field are frequent, and the dominant injuries are in the lower extremity; there is a possibility of recurrence of the same body part injury.

3. Injuries prevalent in sprinter cohort are in lower extremities, and injuries prevalent in throwing cohort are in lower and upper extremities equally.

\section{REFERENCES}

Alonso, J. M., Edouard, P. et al. (2012). Determination of future prevention strategies in elite track and field: Analysis of Daegu 2011 IAAF Championships injuries and illnesses surveillance. British Journal of Sports Medicine, 46, 505-514.

Alonso, J. M., Junge, A., Renström, P. et al. (2009). Sports injuries surveillance during the 2007 IAAF World Athletics Championships. Clinical Journal of Sport Medicine, 19, 26-32.

Alonso, J. M., Tscholl, P. M., Engebretsen, L. et al. (2010). Occurrence of injuries and illnesses during the 2009 IAAF World Athletics Championships. British Journal of Sports Medicine, 44, (1100-1105).
Bahr, R., Krosshaug, T. (2005). Understanding injury mechanisms: A key component of preventing injuries in sport: Review. British Journal of Sports Medicine, 39, 324-329.

Bennell, K. L., Crossley, K. (1996). Musculoskeletal injuries in track and field: Incidence, distribution and risk factors. Australian Journal of Science and Medicine in Sport, 28, 69-75.

D'Souza, D. (1994). Track and field athletics injuries a one-year survey. British Journal of Sports Medicine, 28 (3), 197-202.

Emery, C. A. (2010). Injury prevention in paediatric sport-related injuries: A scientific approach. British Journal of Sports Medicine, 44 (1), 64-69. 
Graff, K., Birken, N. (2009 a). Epidemiologie der Verletzungen in der Leichtathletik. Teil 1. Sport Orthopaedic Trauma 25, 32-40.

Graff, K., Birken, N. (2009 b). Epidemiologie der Verletzungen in der Leichathletik. Teil 2. Sport Ortho Trauma 25, 96-102.

Graff, K., Birken, N. (2009 c). Epidemiologie der Verletzungen in der Leichtathletik. Teil 3. Sport Ortho Trauma, 25, 215-222.

Van Gent, R. N., Siem, D., Van Middelkoop, M. et al. (2007). Incidence and determinants of lower extremity running injuries in long distance runners: A systematic review. British Journal of Sports Medicine, 41, 469-480.

Jacobsson, J., Timpka, T., Kowalski, J. et al. (2012). Prevalence of musculoskeletal injuries in Swedish elite track and field athletes. American Journal of Sports Medicine, 40 (1), 163-169.

Junge, A., Engebretsen, L., Mountjoy, M. L. et al. (2009). Sports injuries during the Summer Olympic Games 2008. American Journal of Sports Medicine, 37 , 2165-2172.
Owoeye, O. B. A., Odunaiya, N., Akinbo, S. R. et al. (2009). A retrospective study of sports injuries reported at the National Sports Medicine Centre, Lagos, SouthWest, Nigeria [2012 11 08]. The Internet Journal of Rheumatology 6 (1). Internet link: http://www.ispub.com/ journal/the-internet-journal-of-rheumatology/volume6-number-1/a-retrospective-study-of-sports-injuriesreported-at-the-national-sports-medicine-centre-lagossouth-west-nigeria.html\#sthash.p3Jk0e81.dpbs

Pastre, C. M., Filho, G. C., Monteiro, H. L. et al. (2004). Sports injuries in track and field: Comparison between information obtained in medical records and reported morbidity inquires. The Revista Brasileira de Medicina do Esporte, 10 (1), 1-8.

Watson, M. D., Di Martino, P. P. (1987). Incidence of injuries in high school track and field athletes and its relation to performance ability. American Journal of Sports Medicine, 15, 251-254.

Zemper, E. D. (2005). Track and field injuries. Journal of Science and Medicine in Sport, 48, 138-151.

\title{
LENGVOSIOS ATLETIKOS SPRINTO IR METIMŲ RUNGČIŲ SPORTININKŲ TRAUMŲ YPATUMAI
}

\author{
Linas Rekus, Evelina Rekuvienė, Aušra Burkauskienė, Daiva Emilija Rekienė, \\ Žibuoklė Senikienė, Audrius Paršeliūnas, Egidijus Šakalys \\ Lietuvos sveikatos moksly universitetas, Medicinos akademija, Kaunas, Lietuva
}

\section{SANTRAUKA}

Tyrimo pagrindimas ir hipotezè. Ivertinus, kurios kūno sritys dažniausiai traumuojamos ir koks lengvosios atletikos sportininkų traumų sunkumo laipsnis, galima koreguoti sportinio rengimo programas.

Tikslas - ivertinti, kurias kūno sritis dažniausiai pažeidžia metikai ir sprinteriai, koks pažeidimo sunkumo laipsnis ir kaip dažnai traumos kartojasi.

Metodai. 36 atletams buvo duota anketa, sudaryta remiantis Tarptautinio olimpinio komiteto patvirtinta standartizuota metodologija ir igyvendinama Tarptautinès lengvosios atletikos federacijos per tarptautines lengvosios atletikos varžybas.

Rezultatai. 33 atletams buvo nustatyti 64 pažeidimų atvejai: galvos ir liemens 12 (18,8\%), rankų 14 (21,9\%), kojų 38 (59,4\%). Taigi kojų pažeidimai dominavo.

Apklausiant sprinterius, vyravo kojų pažeidimai ir nebuvo nė vieno rankų pažeidimo. Tuo tarpu metikai pažymejjo, kad kojos ir rankos buvo traumuojamos vienodai. Labai lengvi ir lengvi pažeidimų atvejai dominavo, palyginti su sunkiais ir labai sunkiais. Tos pačios traumos kartotinumas buvo toks pat abiejose grupèse.

Aptarimas ir išvados. Ivertinus, kurios kūno sritys dažniausiai traumuojamos sportinèje veikloje, galima koreguoti sportininkų rengimo programas didinant atletinio rengimo pratimų apimtis, skirtas šių kūno dalių funkciniam parengtumui ugdyti. Kojų pažeidimai yra dažniausiai pasitaikanti lengvosios atletikos sportininkų trauma. Didelẻ tikimybė tai pačiai traumai pasikartoti. Tarp sprinterių vyrauja kojų pažeidimai, tarp metikų - kojų ir rankų.

Raktažodžiai: lengvoji atletika, sportinè trauma, kūno sritys.

Gauta 2012 m. spalio 17 d.

Received on October 17, 2012

Priimta 2013 m. kovo $8 \mathrm{~d}$.

Accepted on March 8, 2013
Corresponding author Linas Rekus

Lithuanian University of Health Sciences

A. Mickevičiaus str. 9, LT-44307 Kaunas

Lithuania

Tel +37067633724

E-mail rekfiuler@gmail.com 